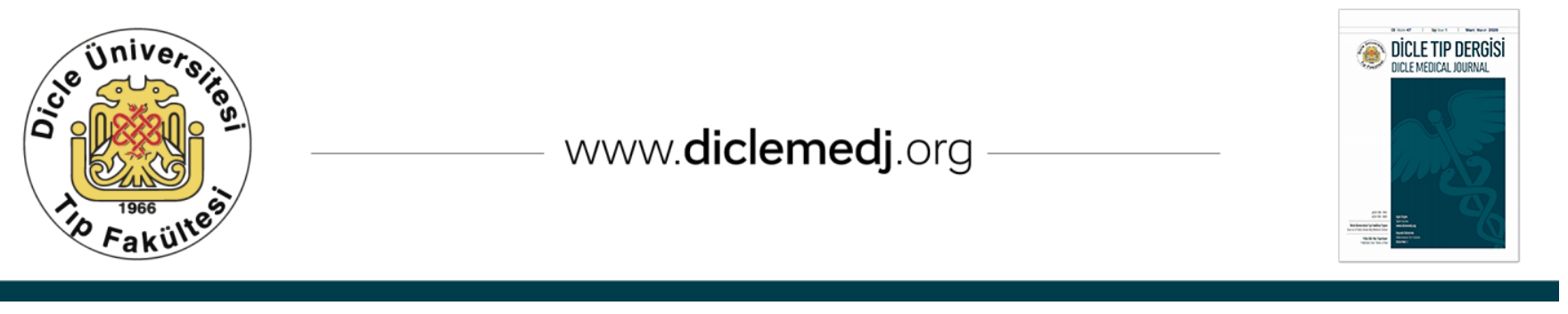

Original Article / Özgün Araştırma

\title{
Comparison Of Monocyte / HDL Ratio In Routine Hemodialysis And Peritoneal Dialysis Patients
}

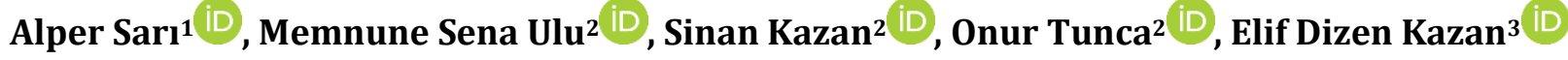 \\ 1 Afyonkarahisar State Hospital, Internal Medicine Clinic, Afyonkarahisar, Turkey \\ 2 Afyon Health Sciences University Hospital, Nephrology Department, Afyonkarahisar, Turkey \\ 3 Afyon Health Sciences University Hospital, Internal Medicine Department, Afyonkarahisar, Turkey \\ Received: 04.02.2020; Revised: 03.03.2020; Accepted: 05.03.2020
}

\begin{abstract}
Objective: Chronic kidney disease (CKD) is an inflammatory process. Serum proinflammatory cytokines are known to be ten times higher in patients with CKD when compared to normal population. Monocyte/High density lipoprotein (HDL) cholesterol ratio (MHR) have been shown to be a new marker of inflammation and claimed that, it may be used to predict cardiovascular events in patients with CKD. This cross-sectional study aimed to compare monocyte / HDL cholesterol ratio in patients treated with hemodialysis and peritoneal dialysis.
\end{abstract}

Methods: Files of patients who have been followed up with end stage renal disease (ESRD) and have peritoneal dialysis or hemodialysis therapy in Nephrology Clinic of our hospital have been retrospectively examined. Patients were divided into two groups regarding renal replacement treatment type. Monocyte / HDL cholesterol ratio was compared between groups. IBM SPSS Statistics 22.0 (IBM Corp., NY, USA) packaged software and appropriate statistical methods were used to analyse data.

Results: Monocyte / HDL cholesterol ratio was significantly higher in patients treated with hemodialysis ( $\mathrm{p}=0.028)$. HDL cholesterol levels were significantly higher in peritoneal dialysis group $(p=0.046)$. Total cholesterol, LDL cholesterol, triglyceride and VLDL cholesterol have been ascertained to be similar in both patient groups ( $\mathrm{p}>0.05)$. The high sensitivity CRP and sedimentation levels have been detected to be similar within the groups ( $p>0.05)$.

Conclusion: This is the first study evaluating the monocyte/HDL cholesterol ratio among renal replacement therapy modalities in our literature review. In this study, it has been shown that; monocyte/HDL cholesterol ratio were statistically higher in patients having hemodialysis than in the ones followed up with peritoneal dialysis. According to these results, it may be considered that; peritoneal dialysis may be associated with less systemic inflammation than hemodialysis.

Keywords: dialysis, inflammation, monocyte, peritoneal dialysis

DOI: 10.5798/dicletip.706097

Correspondence / Yazışma Adresi: Memnune Sena Ulu, Afyon Health Sciences University Hospital, Nephrology Department, Afyonkarahisar, Turkey email:drsenaulu@yahoo.com 


\section{Rutin Hemodiyaliz Ve Periton Diyalizi Hastalarında Monosit/HDL Kolesterol Oranının Karşılaştırılması}

$\ddot{0} \mathbf{z}$

Amaç: Kronik böbrek hastalığı (KBH) inflamatuar bir süreçtir. KBH hastalarında serum proinflamatuar sitokinlerininin normal popülasyona göre on kat daha yüksek olduğu bilinmektedir. Monosit/HDL kolesterol oranının yeni bir inflamatuar belirteç olduğu gösterilmiştir ve KBH hastalarında kardiyovasküler olayları tahmin etmede kullanılabileceği iddiaa edilmiştir. Bu kesitsel çalışma ile, hemodiyaliz ve periton diyalizi ile tedavi alan hastalarda monosit/HDL kolesterol oranının karş̧laştırılması amaçlamıştır.

Yöntemler: Nefroloji kliniğimizde son dönem böbrek yetmezliği ile takip edilen ve periton diyalizi veya hemodiyaliz tedavisi alan hastaların dosyaları retrospektif olarak incelendi. Renal replasman tipine göre hastalar iki gruba ayrıldı. Gruplar arasında Monosit/HDL kolesterol oranı karşılaştırıldı. Verilerin analizi için IBM SPSS Statistics 22.0 (IBM Corp., NY, ABD) programı ile uygun istatistiksel yöntemler kullanıldı.

Bulgular: Monosit/HDL kolesterol oranı HD ile tedavi alan hastalarda anlamlı şekilde yüksek bulundu ( $\mathrm{p}=0.028)$. HDL kolesterol seviyeleri periton diyalizi grubunda anlamlı şekilde yüksekti $(\mathrm{p}=0.046)$. Total kolesterol, LDL kolesterol, trigliserid ve VLDL kolesterol hasta grupları arasında benzer olarak tespit edildi ( $p>0.05)$. Yüksek sensitiviteli CRP ve sedimentasyon düzeyleri gruplar arasında benzer bulundu ( $p>0.05)$.

Sonuç: Literatür taramamıza göre bu çalışma renal replasman tedavi modaliteleri arasında monosit/HDL kolesterol oranını değerlendiren ilk çalışmadır. Bu çalışmada monosit/HDL kolesterol oranının hemodiyaliz alan hastalarda periton diyalizi ile takip olanlara göre anlamlı şekilde yüksek olduğu gösterilmiştir. Bu sonuçlara göre periton diyalizinin hemodiyalize göre daha az sistemik inflamasyon ile ilişkili olabileceği düşünülebilir.

Anahtar kelimeler: Diyaliz, inflamasyon, monosit, periton diyalizi.

\section{INTRODUCTION}

Chronic kidney disease (CKD) is defined as glomerular filtration rate (GFR) of $<60 \mathrm{ml} / \mathrm{min} / 1.73 \mathrm{~m} 2$ for more than 3 months or presence of renal damage symptoms for more than 3 months apart from GFR. In our country, Diabetes Mellitus (DM), hypertension (HT) and chronic glomerulonephritis are ranked among the top three in CKD etiology ${ }^{1}$. Chronic renal failure is an inflammatory process. The symptoms accompanying uremia and uremic syndrome activate proinflammatory cytokines. As a result, serum proinflammatory cytokines are known to be ten times higher in patients with CKD when compared to normal population ${ }^{2,3}$. Glycolysis products and protein oxidation products have also been shown to cumulate and play a part in inflammation ${ }^{4,5}$. In chronic renal failure patients, hemodialysis (HD), peritoneal dialysis (PD), and renal transplantation are renal replacement therapy (RRT) options. The parameters such as patient's age, comorbidities, sociocultural level,vascular structure have determining role in deciding which therapy to be applied 6 .

Monocytes and macrophages are the cells that have significant role in cytokine synthesis. The high density lipoprotein (HDL) is known to play a part in the anti-inflammatory process that protects the endothelium from detrimental effect of low density lipoprotein (LDL) ${ }^{7,9}$. The clinical trials conducted in recent years have shown that monocyte/HDL ratio (MHR) might be a new marker of inflammation ${ }^{10,11}$. Previous studies that claimed that, MHR may be related with the risk of contrast nephropathy development and monocyte and HDL cholesterol levels of patients with CKD may be used to predict their cardiovascular events ${ }^{12,13}$. 
This cross-sectional study aims to compare MHR levels of patients who have HD and PD as renal replacement therapy.

\section{METHODS}

\section{Patients}

Files of patients who have been followed up with end stage renal failure (ESRF) and have PD or HD therapy in Nephrology Clinic of our hospital have been retrospectively examined. The following parameters have been determined as the exclusion criteria in the present study: Being either younger than 18 or older than 85 , having active infection findings by the moment of examination, having history of chronic infection, hematologic or oncologic disease and autoimmune disease. PD patients having peritonitis attacks during and one month before the study were also excluded.

Demographic data and laboratory values of all patients have been recorded. Thorough medical history taking and systemic physical examination have been performed to all patients so as to record their chronic diseases and medication.

\section{Laboratory Tests}

Study data have been obtained from hemogram and biochemical parameters that are studied routinely. The complete blood count and biochemical parameters have been practised on the blood that is drawn in the morning after at least 8 hours of fasting. HD patients' blood was drawn before receiving dialysis treatment. The complete blood count have been practised by BC-6800 machine (Mindray Medical USA Corp Address: 8650 154th Avenue, Northeast Redmond, WA 98052, USA). Serum glucose levels; enzymatic UV test (Hexokinase method), creatinine; kinetical coulometric method (Jaffe method), urea; kinetical UV test, total cholesterol, triglyceride and HDL have been practised with enzymatic coulometric method by Roch Cobas C501 autoanalyzer. LDL has been calculated by Friedewald formula [LDL= Total Cholesterol- (HDL + Triglyceride/5)].

Body mass index has been calculated by dividing the weight $(\mathrm{kg})$ of the patients by the square of their height (m2). Absolute monocyte count has been recorded as an average of absolute monocytes in the 3 complete blood counts measured in every other month and HDL cholesterol has also been recorded as an average of 3 HDL cholesterol measured in every other month. MHR has been calculated by dividing the absolute monocyte count by HDL cholesterol.

\section{Statistical Analysis}

IBM SPSS Statistics 22.0 (IBM Corp., NY, USA) packaged software has been used to analyse data. Continuous variables' suitability to normal distribution has been controlled by ShapiroWilk test. Chi-square test has been performed in comparing the categorical data of PD and HD patients. The normally distributed parameters of the patient groups have been compared by the Student's t-test and the non-normally distributed variables have been compared by Mann-Whitney $U$ test. All $p$ values are bidirectional and the ones that are $p \leq 0.05$ have been statistically considered as significant.

\section{RESULTS}

The study has been conducted with 27 PD (57.4\%) and 20 HD (42.6\%) patients. Median RRT durations in PD group have been detected as 29 months (min-max: 6-174 months) while they have been detected as 38.5 months (minmax: 9-284 months) in HD group. Median RRT durations have been found similar in PD and HD groups( $p>0.05)$. The demographic features, CKD etiologies and comorbidities of patient groups have been similar ( $p>0.05$ ) (Table I). 
Table I: Demographic features and comorbidities of the patients

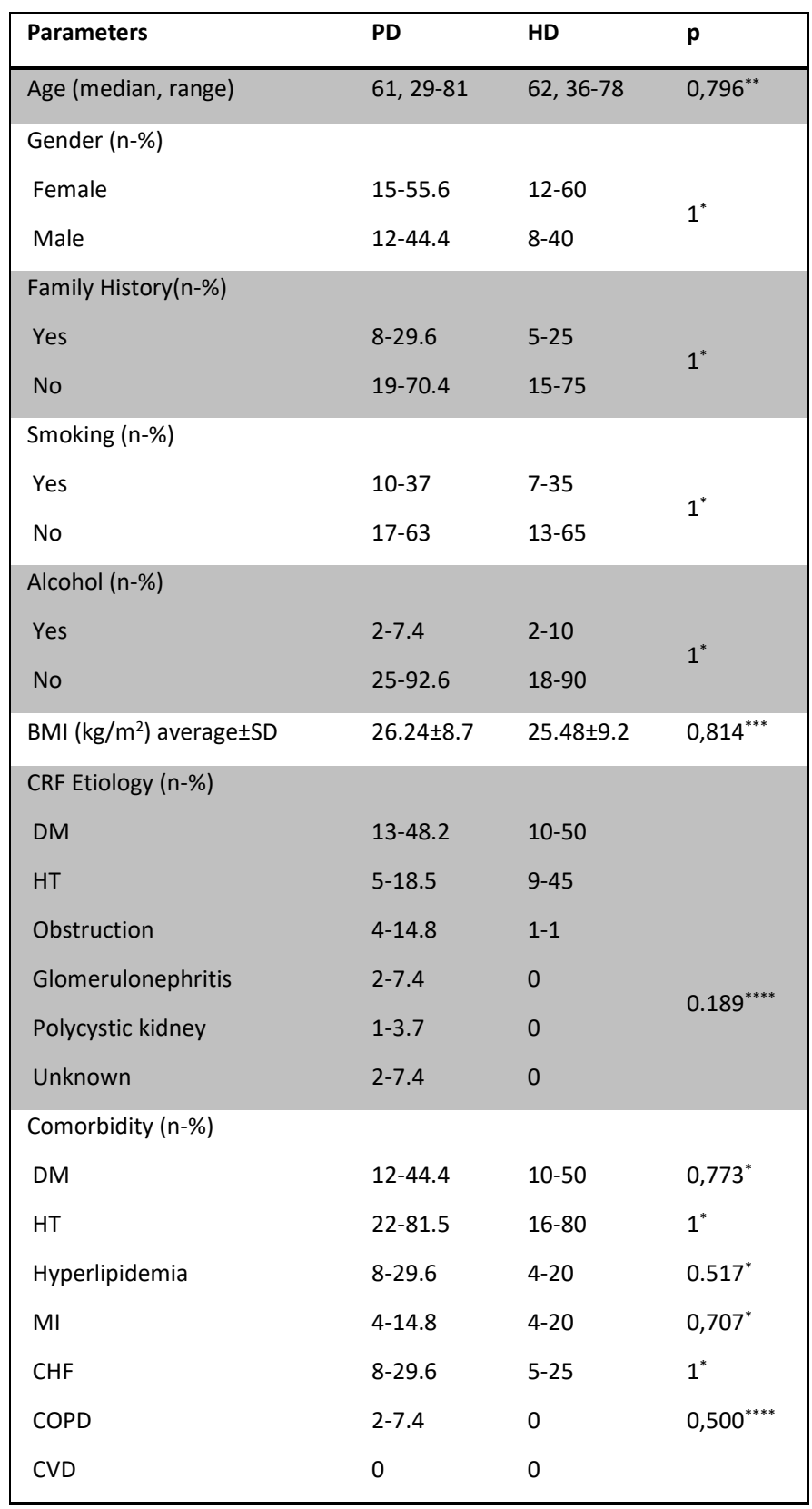

*Fisher's Exact test, **Mann Whitney U test, ${ }^{* * *}$ Student's T test, ${ }^{* * * *}$ Chi-square test

There have been no differences between the medications of the patients aside from the two of them ( $p>0.05)$. It has been detected that, the loop diuretic and sodium hydrogen carbonate usage have been significantly higher in PD group than HD group $(\mathrm{p}=0.02$ and $\mathrm{p}=0.007$ respectively). Table II shows the patients' medications.
Table II: Comparison of patients' medications

\begin{tabular}{|c|c|c|c|}
\hline Medication & PD (n-\%) & HD (n-\%) & p \\
\hline ACE inhibitor & $2-7.4$ & $5-25$ & $0.119^{*}$ \\
\hline ARB & $10-37$ & $4-20$ & $0.334^{*}$ \\
\hline CCB & $15-55.6$ & $10-50$ & $0.773^{*}$ \\
\hline$\beta$-Blocker & $6-22.2$ & $6-30$ & $0.737^{*}$ \\
\hline Thiazide & $6-22.2$ & $4-20$ & $1^{*}$ \\
\hline Furosemide & $13-48.1$ & 3-15 & $0.02^{*}$ \\
\hline Alfa-Blocker & $8-29.6$ & $4-20$ & $0 ., 517^{*}$ \\
\hline Phosphate Binder & $20-74.1$ & $15-75$ & $1^{*}$ \\
\hline $\begin{array}{l}\text { Sodium } \\
\text { carbonate }\end{array}$ & $17-63$ & $4-20$ & $\mathbf{0 . 0 0 7}^{*}$ \\
\hline Iron preparation & $12-44.4$ & $3-15$ & $0.056^{*}$ \\
\hline Erythropoietin & $6-22.2$ & $6-30$ & $0.737^{*}$ \\
\hline Vitamin D & $12-44.4$ & $4-20$ & $0.121^{*}$ \\
\hline Cinacalcet & $3-11.1$ & $3-15$ & $1^{*}$ \\
\hline Statin & $8-29.6$ & $3-15$ & $0.310^{*}$ \\
\hline ASA & $6-22.2$ & $9-45$ & $0.122^{*}$ \\
\hline
\end{tabular}

${ }^{*}$ Fisher's Exact test

The laboratory values show that serum urea, potassium and albumin levels were higher in HD group $(\mathrm{p}=0.004, \mathrm{p}<0.001$ and $\mathrm{p}=0.001$ respectively) but other laboratory parameters were similar with each other. When the complete blood count parameters have been compared, only Mean Corpuscular Volume (MCV) value has been detected to be significantly higher in HD group than in PD group ( $p=0.025)$. Other hemogram parameters have been found out to be similar between the groups ( $p$ $>0.05$ ). When cholesterol parameters were compared, HDL cholesterol levels were significantly higher in PD group $(\mathrm{p}=0.046)$. Total cholesterol, LDL cholesterol, triglyceride and VLDL cholesterol have been ascertained to be similar in both patient groups ( $p>0.05)$. The high sensitivity CRP and sedimentation levels have been detected to be similar within the groups ( $p>0.05)$. Table III shows the patients' laboratory parameters. Monocyte/HDL cholesterol ratio was significantly higher in HD patients $(p=0.028)$. Figure 1 shows the patients' monocyte/HDL ratio according to their RRT. 
Table III: Comparison of patients' laboratory values

\begin{tabular}{|c|c|c|c|}
\hline Parameter & $\begin{array}{c}\text { PD } \\
\text { [avg } \pm \text { SD or } \\
\text { median(range)] }\end{array}$ & $\begin{array}{c}\text { HD } \\
\text { [avg } \pm \text { SD or } \\
\text { median(range)] }\end{array}$ & $\mathbf{p}$ \\
\hline $\mathrm{pH}$ & $7,39 \pm 0,04$ & $7,4 \pm 0,06$ & $0,441^{*}$ \\
\hline $\mathrm{HCO}_{3}(\mathrm{mmol} / \mathrm{L})$ & $24,83 \pm 6,07$ & $24,53 \pm 4,08$ & $0,850^{*}$ \\
\hline Urea(mg/dl) & $104,17 \pm 25,3$ & $126,96 \pm 25,9$ & $0,004^{*}$ \\
\hline Creatinine(mg/dl) & $6,88 \pm 2,7$ & $7,15 \pm 2,07$ & $0,713^{*}$ \\
\hline $\mathrm{K}^{+}(\mathrm{mmol} / \mathrm{L})$ & $4,47 \pm 0,56$ & $5,32 \pm 0,76$ & $<0,001^{*}$ \\
\hline Total protein(mg/dl) & $6,48 \pm 0,76$ & $6,86 \pm 0,86$ & $0,119 *$ \\
\hline $\operatorname{Albumin}(\mathrm{mg} / \mathrm{dl})$ & $3,46(2-4)$ & $3,98(2-5)$ & $0,001^{* *}$ \\
\hline $\operatorname{AST}(\mathrm{U} / \mathrm{L})$ & $13,35 \pm 4,5$ & $13,17 \pm 4,28$ & $0,887^{*}$ \\
\hline ALT(U/L) & $11,5(0-33)$ & $9,90(5-20)$ & $0,447^{* *}$ \\
\hline $\operatorname{Iron}(\mathrm{ug} / \mathrm{dl})$ & $65,3(5-244)$ & $75,3(34-158)$ & $0,206^{* *}$ \\
\hline TIBC(ug/dl) & $195,39 \pm 54,1$ & $182,18 \pm 25,1$ & $0,318^{*}$ \\
\hline $\mathrm{B} 12(\mathrm{pg} / \mathrm{mL})$ & 487 (345-1727) & $471(137-2000)$ & $0,865^{* *}$ \\
\hline Folate(ng/mL) & $4,87(2-20)$ & $4,93(3-17)$ & $0,865^{* *}$ \\
\hline Sedimentation(mm/hour) & $26,59 \pm 8,2$ & $18,95 \pm 9,3$ & $0,601^{*}$ \\
\hline $\mathrm{CRP}(\mathrm{mg} / \mathrm{L})$ & $1,02(0-1,6)$ & $0,52(0-1,6)$ & $0,447^{* *}$ \\
\hline $\mathrm{TSH}(\mathrm{uIU} / \mathrm{ml})$ & $2,32(0-4)$ & $1,5(0-3)$ & $0,052^{* *}$ \\
\hline sT3(ng/dL) & $2,24(0,98-4)$ & $2,28(0,9-6,1)$ & $0,766^{* *}$ \\
\hline sT4(ng/dL) & $1,13(0,89-2)$ & $1,15(0,73-2,51)$ & $0,766^{* *}$ \\
\hline Total Cholesterol(mg/dL) & $180,89 \pm 39,06$ & $164,97 \pm 28,06$ & $0,128^{*}$ \\
\hline $\mathrm{HDL}(\mathrm{mg} / \mathrm{dL})$ & $40,38 \pm 12,2$ & $32,88 \pm 10,9$ & $0,036^{*}$ \\
\hline $\mathrm{LDL}(\mathrm{mg} / \mathrm{dL})$ & $115 \pm 31,7$ & $100,62 \pm 18,9$ & $0,079 *$ \\
\hline Triglyceride(mg/dL) & $127,8(50-427)$ & $187,75(89-395)$ & $0,312^{* *}$ \\
\hline VLDL(mg/dL) & $25,28(10-86)$ & $37,15(18-79)$ & $0,312^{* *}$ \\
\hline Leukocyte $\left(10^{\wedge} 3 \mathrm{u} / \mathrm{L}\right)$ & $7350 \pm 2085$ & $7475 \pm 2240$ & $0,846^{*}$ \\
\hline Neutrophile $\left(10^{\wedge} 3 \mathrm{u} / \mathrm{L}\right)$ & $5177 \pm 1664$ & $5020 \pm 1799$ & $0,758^{*}$ \\
\hline Lymphocyte $\left(10^{\wedge} 3 \mathrm{u} / \mathrm{L}\right)$ & $1459 \pm 802$ & $1529 \pm 517$ & $0,735^{*}$ \\
\hline Monocyte $\left(10^{\wedge} 3 \mathrm{u} / \mathrm{L}\right)$ & $420(50-930)$ & $460(310-870)$ & $0,312^{* *}$ \\
\hline $\mathrm{Hb}(\mathrm{g} / \mathrm{dl})$ & $10,7(9-15)$ & $10,8(8-13)$ & $0,796^{* *}$ \\
\hline Hct $(\%)$ & $35,47 \pm 4,1$ & $33,99 \pm 3,5$ & $0,204^{*}$ \\
\hline $\operatorname{MCV}(f L)$ & $89,79 \pm 5,4$ & $93,60 \pm 5,6$ & $0,025 *$ \\
\hline $\operatorname{PLT}\left(10^{\wedge} 3 \mathrm{u} / \mathrm{L}\right)$ & $231 \pm 65,4$ & $206 \pm 61,5$ & $0,182^{*}$ \\
\hline MPV(fL) & $9,2(7-13)$ & $9,15(7-12)$ & $0,935^{* *}$ \\
\hline MHR & $10(2,08-41,52)$ & $\begin{array}{c}16,3(6,35- \\
33,81)\end{array}$ & $0,028 * *$ \\
\hline
\end{tabular}

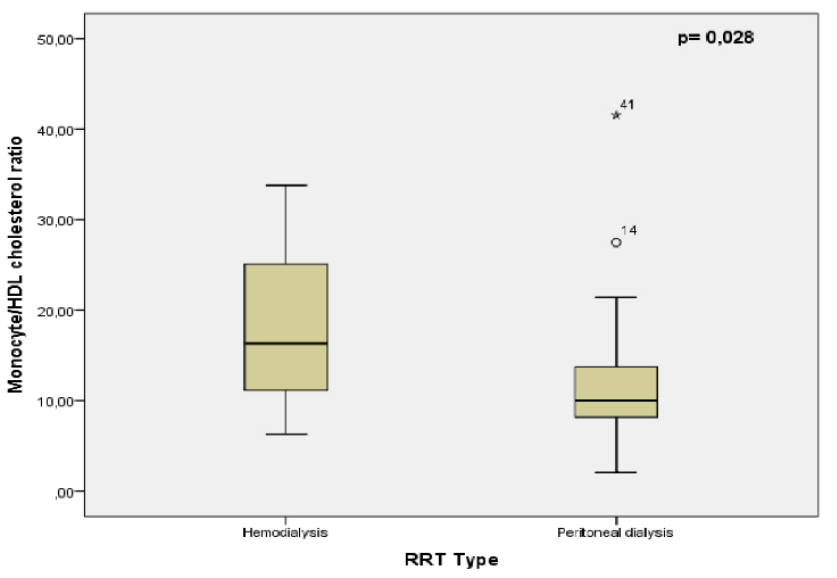

Figure 1. Comparison of MHR according to RRT type

\section{DISCUSSION}

This is the first study comparing monocyte/HDL ratio among RRT modalities in our literature review, which makes the present study a prominent one. In this study, it has been shown that; monocyte/HDL ratio were statistically higher in patients having HD than in the ones followed up with PD.

Endothelial damage and inflammation begins to occur at the first stage of CKD and exacerbate its progression as well ${ }^{14}$. It has been shown that, the chronic inflammation can be seen frequently in patients with ESRD and exacerbates the increased atherosclerosis and mortality ${ }^{15}$. It has also been depicted in some research that systemic inflammation markers such as high sensitive CRP (hsCRP), interleukin12 and interleukin-18 in patients with ESRD have doubled or tripled 15,16 .

Monocytes are one of the types of the cells differentiating from myeloid stem cells in bone marrow and play a part in the development of atherosclerosis by synthesizing proinflammatory and prooxidant cytokines ${ }^{7}$. Studies have shown that the number of 
circulating monocytes foresee new plaque formation in the atherosclerotic process ${ }^{17}$. HDLcholesterol gets into circulation immaturely through liver and kidneys. It maturates as it takes free cholesterol from peripheral tissues. HDL transports cholesterol from peripheral tissues and other lipoproteins to the liver ${ }^{18}$. High HDL cholesterol is considered as a negative risk factor and it is seen as protective from atherosclerosis.

Monocyte/HDL-cholesterol ratio is a new indicator of inflammation which increases as the increased number of monocytes which play an active role in inflammation or the amount of antioxidant and anti-inflammatory HDLcholesterol decreases. There are many clinical conditions in which monocyte/HDL-cholesterol ratio increases as an indicator of systemic inflammation 19,23. Monocyte/HDL cholesterol ratio has recently become popular since it is an easily accessible parameter. However, there is no study comparing monocyte/HDL ratio among RRT modalities in our literature review, which makes the present study a prominent one. In this study, it has been found out that monocyte/HDL ratio has been statistically higher in the patients having HD than in the ones followed up with PD. The detection of different monocyte/HDL-cholesterol ratio which is considered as an indicator of chronic inflammation in two patient groups which have similar traditional risk factors for atherosclerosis and similar median RRT durations, suggests that this parameter may exacerbate the development and progression of atherosclerosis.

High level of HDL-cholesterol in PD patients may have led to detect lower MHR level in this group but lower $\mathrm{p}$ value only in the MHR comparison suggests that MHR is different from HDL-cholesterol in both groups. The detection of different MHR in the two groups that are quite similar in demographic and etiological aspects and have similar other inflammation markers such as hs-CRP, leukocyte, sedimentation suggests that this parameter can show inflammation better. There are studies which have shown that PD may be more advantageous than HD in cardiovascular mortality aspect ${ }^{24}$. In the first few years of RRT, PD is known to have a survival benefit ${ }^{25}$. MHR may play a role in this survival benefit.

It is a restriction of the present study that it is not possible to establish cause and effect relation due to the fact that it includes a limited number of patients and is cross-sectional. The study also has another restriction since the effects of MHR on cardiovascular mortality have not been explored. More comprehensive studies which investigate the relation between MHR and dialysis modalities together with cardiovascular mortality may provide more clear understanding of this topic.

Ethics Committee Approval: The present study was approved by Afyon Kocatepe University Ethics Committee of Clinical Studieswith the decision dated 01.12.2017 numbered 2017/12-298.

Conflicts of interest: The authors have no conflict of interests to declare.

Financial Disclosure: The authors declared that this study has received no financial support.

\section{REFERENCES}

1. National Kidney Foundation. K/DOQI Clinical Practice Guidelines for Chronic Kidney Disease: Evaluation, Clasification and Stratification. Am J Kidney Dis. 2002; Vol. 39: 1-266

2. Zyga S, Christopoulou G, Malliarou M. Malnutrition-inflammation-atherosclerosis syndrome in patients with end-stage renal disease. J Ren Care. 2011; 37: 12-5.

3. Tonbul HZ, Demir M, Altintepe L, et al. Malnutrition-Inflammation-Atherosclerosis 
syndrome componentsin hemodialysis and peritoneal dialysis patients. 2006; 24: 287-94.

4. Rao P, Reddy GC, Kanagasabapathy AS. Malnutrition-inflammation-atherosclerosis syndrome in Chronic Kidney disease. Indian J Clin Biochem. 2008; 23: 209-17.

5. Stenvinkel P. Inflammation in end-stage renal failure: could it be treated? Nephrol Dial Transpl. 2002; 17 Suppl 8: 33-8; discussion 40.

6. Daugirdas JT, Blake P, Ing TS, et al. Handbook of Dialysis, Fourth Edition. Dial Transplant. 2007; 36: 322.

7. Ancuta P, Wang J, Gabuzda D. CD16+ monocytes produce IL-6, CCL2, and matrix metalloproteinase-9 upon interaction with CX3CL1-expressing endothelial cells. J Leukoc Biol. 2006; 80: 1156-64.

8. Hessler JR, Robertson AL, Chisolm GM. LDLinduced cytotoxicity and its inhibition by HDL in human vascular smooth muscle and endothelial cells in culture. Atherosclerosis. 1979; 32: 21329.

9. Li XP, Zhao SP, Zhang XY, et al. Protective effect of high density lipoprotein on endothelium-dependent vasodilatation. Int J Cardiol. 2000; 73: 231-6.

10. Canpolat U, Çetin EH, Cetin S, et al. Association of Monocyte-to-HDL Cholesterol Ratio with Slow Coronary Flow is Linked to Systemic Inflammation. Clin Appl Thromb. 2016; 22: 476-82.

11. Canpolat U, Aytemir K, Yorgun H,et al. The role of preprocedural monocyte-to-highdensity lipoprotein ratio in prediction of atrial fibrillation recurrence after cryoballoon-based catheter ablation. Europace. 2015; 17: 1807-15.

12. Ulus $\mathrm{T}$, Isgandarov $\mathrm{K}$, Yilmaz $\mathrm{AS}$, et al. Monocyte to High-Density Lipoprotein Ratio predicts Contrast-Induced Nephropathy in Patients With Acute Coronary Syndrome. Angiology 2018 Nov; 69: 909-16
13. Rogacev KS, Zawada AM, Emrich I, et al. Lower Apo A-1 and lower HDL-C levels are associated with higher intermediate CD14++CD16+ monocyte counts that predict cardiovascular events in chronic kidney disease. Arterioscler Thromb Vasc Biol. 2014; 34: 2120 7.

14. Nahas M El. Chronic renal failure and uremic syndrome. Progression of chronic renal failure. In: Comprehensive Clinical Nephrology Masby (Elsevier Limited) 2nd edition Philadelphia, Pennsylvania, USA; 2003; p. 843-56.

15. Stenvinkel $P$, Alvestrand A. Inflammation in end-stage renal disease: Sources, consequences, and therapy. Vol. 15, Seminars in Dialysis 2002;p. 329-37.

16. Yong K, Ooi EM, Dogra G, et al. Elevated interleukin-12 and interleukin-18 in chronic kidney disease are not associated with arterial stiffness. Cytokine. 2013; 64: 39-42.

17. Johnsen SH, Fosse E, Joakimsen O, et al. Monocyte count is a predictor of novel plaque formation: A 7-year follow-up study of 2610 persons without carotid plaque at baseline the Troms?? study. Stroke. 2005; 36: 715-9.

18. National Cholesterol Education Program (NCEP) Expert Panel on Detection Evaluation and Treatment of High Blood Cholesterol in Adults (Adult Treatment Panel III). Third Report of the National Cholesterol Education Program (NCEP) Expert Panel on Detection, Evaluation, and Treatment of High Blood Cholesterol in Adults (Adult Treatment Panel III) final report. Circulation. 2002; 106: 3143421. ,

19. Efe TH, Arslan ED, Ertem AG, et al. Akut Pulmoner Emboli Hastalarında Monosit / HDL Oranının Kısa Dönem Mortaliteyi Ön Gördürmedeki Prognostik Değeri. 2016; 19: 149-53.

20. Ucar FM. A potential marker of bare metal stent restenosis: Monocyte count - to- HDL 
cholesterol ratio. BMC Cardiovasc Disord. 2016; 16: 1-7.

21. Koçak HE, Acipayam H, Elbistanli MS, et al. Is the monocyte/HDL ratio a prognostic marker of idiopathic sudden hearing loss? Otolaryngol Pol. 2016; 70: 6-10.

22. Kanbay M, Solak Y, Unal HU, et al. Monocyte count/HDL cholesterol ratio and cardiovascular events in patients with chronic kidney disease. Int Urol Nephrol. 2014; 46: 1619-25.

23. Katipoglu B, Ates I, Demir BF, et al. Relationship between monocyte/HDL cholesterol ratio and urinary protein excretion in patients with primary hypertension with reverse dipper pattern. Turk J Nephrol 2019; 28: 54-61.

24. Refaat H, Sany D, Mohab A, et al. Comparing Dialysis Modality and Cardiovascular Mortality in Patients on Hemodialysis and Peritoneal Dialysis. Adv Perit Dial. 2016; 32: 22-31.

25. Tokgoz B. Clinical advantages of peritoneal dialysis. Perit Dial Int. 2009 Feb; 29 Suppl 2: S59-61. 